International Journal of Environment, Agriculture and Biotechnology
Vol-6, Issue-4; Jul-Aug, 2021
JUAB
$\begin{gathered}\text { Journal Home Page Available: } \text { https://ijeab.com/ } \\ \text { Journal DOI: } 10.22161 / \text { ijeab }\end{gathered}$

Article

Peer-Reviewed Journal

\title{
Ethnobotanical Study of Wild Edible Plants in Pyuthan, Nepal
}

\author{
Sangam Panta ${ }^{1 *}$, Dipika Parajulee ${ }^{2}$, Ganesh Subedi $^{3}$, Bhuvvan Giri ${ }^{4}$
}

\author{
${ }^{1}$ Agriculture and Forestry University (AFU), Chitwan, Nepal \\ ${ }^{2}$ Nepal Polytechnic Institute (NPI), Purbanchal University, Chitwan, Nepal \\ ${ }^{3}$ D.D.college, HNB Garhwal central University, Dehradhun, India \\ ${ }^{4}$ IMMT college, HNB Garhwal central University, Dehradhun, India \\ Corresponding author
}

Received: 05 Jul 2021; Received in revised form: 17 Jul 2021; Accepted: 25 Jul 2021; Available online: 07 Aug 2021 (C)2021 The Author(s). Published by Infogain Publication. This is an open access article under the CC BY license (https://creativecommons.org/licenses/by/4.0/).

\begin{abstract}
Wild edible plants are those plants that are not domesticated and often neglected but have nutritional and medicinal value and can be used as a good source of diet. The study discusses and depicts the availability of wild edible plants, their taxonomical categories, species richness, distribution, preference, and their threat in the Gaumukhi area. Data were collected from 60 randomly selected wild edible plant consumers of Puja and Khung village using a semi-structured interview schedule. The study showed that 37 different species of wild plants are frequently used by respondents. It was found that the majority of the WEP's used were trees followed by herbs and shrubs. It was found that majority of WEP's used were trees followed by herbs and shrubs. Regarding the plant parts used, most of the respondents (54\%) use WEP's in the form of vegetables followed by raw fruits (28\%) users. The study revealed that the majority of WEP's consumers (39\%) were from other caste categories like Giri, Puri, Malla, etc. followed by Dalits (36\%). Research indicated that most of the WEPs were collected from the forest area having an altitude of (1300-1500) masl. The major threat to wild edible plants was fuel wood collection followed by uncontrolled fire. Study preference of WEP's among the respondents showed that Polystichumsquarrosum (Daude) was the highly preferred one followed by Diplaziumesculentum (Neuro) and Dendrocalamushamiltoni (Tama).
\end{abstract}

Keywords-WEP, Gaumukhi, Ethnicity, Habitat, Threat.

\section{INTRODUCTION}

Nepal, being a small country, occupying just $0.1 \%$ of the global area is rich in its biodiversity, both in plant and animal diversity and cultural diversity (MoFSC, 2014). The country is bestowed with climatic variation and unique geography which provides diversified topography. The ecologically rich environment and the multi-ethnic population is a unique and attractive attribute of the country. Biodiversity and cultural diversity come together as we know; different ethnic groups depend on biodiversity for their food security. Nepal is rich in wild edible plants growing in different ecosystems and such plants along with their wild relatives enrich the genetic diversity in the country.

About 1500 species of plants found in Nepal are considered to be useful (Manandhar, 2002). Out of these, 651 species are economically useful including 440 species as wild food plants. Total 394 wild plants are recorded to be in use in different purposes such as vegetables (246 spp), fruits (125 spp), pickle (44 spp), jam (11 spp), spices and condiments (10 spp), oil (6 spp) and other uses (Dangolet.al 2017). During food scarcity, people from both, urban and rural communities highly depend on natural habitats to gather edible fruits and vegetables (Manandhar, 1982). Although many agricultural societies 
depend on conventional crop plants, the tradition of eating wild edible plants has not been completely abandoned (Lockettet.al 2000). Gathering the indigenous edible plants for both, self-consumption and sales is usually common in Nepal in most of the rural communities.

Wild edible plants (WEP) are those plant species that are not domesticated but are available through natural habitation and are used as food (Bhatia, 2018). They are the source of nutrients, medicine, fuel, fodder, and spices. Also, its fresh, aromatic taste, pollution-free growing environment, and strong vitality are favorable for people to utilize the WEPs (Yilinet.al2020). Even though the world is modernized, there are still poor and marginalized populations in the rural areas who are highly dependent on wild edible plants. These neglected groups of food plants can absolutely contribute their part in ensuring food security, increasing agricultural diversification, income generation, and poverty reduction (Ashagreet.al 2016). In many developing countries, millions of people do not have enough food supply to meet their requirements and in such cases, rural communities depend on wild resources to meet their need of food (K \& F, 2006). Rural area people not only use wild plants as their source of food and medicine but also help in its conservation. WEP is used as a staple food for indigenous people, complementary food for nonindigenous people, and offers alternative cash-generating sources (Upretyet.al 2012). Household harvesting of wild plants and value addition to it can boost rural employment and bring profit to local communities (Gautamet.al 2020).

Despite being important to food security and livelihood, these plants are still in wild forms. Many valuable wild plants are familiar to certain groups and communities but unnoticed and unknown by others as they are in a wild state. Also, the rapid reduction in usage of wild plants and reliance on processed food makes it crucial to have information on the status of WEP (Upretyet.al 2012). The information and utilization of WEP is majorly confined to local people so many scientists are interested to understand and disseminate it on various platforms. Many researches and studies were focused on wild edible fruit plants (Gautamet.al 2020) and some research were on wild edible plants in various other districts like Palpa, Rupandehi, etc[(Acharya\&Acharya, 2010), (Mahato, 2014)]. No research has been found to be studied on WEP in Pyuthan district. This paper has attempted to compile and analyze the information on wild edible plants along with their plant parts, uses, the local and scientific names which are available, utilized, and unutilized in the Pyuthan district.

\section{METHODOLOGY}

\subsection{Study site}

Pyuthan district was selected purposively for the study site as it is well known as the home of various indigenous wild plants for a long time. The study was carried out in Ward no.5 (Khung) and ward no.4 (Puja) of Gaumukhi Rural municipality in Pyuthan, Nepal. The reason behind the selection is that people around those areas mostly depend on wild plants as a source of their living. Among the consumers, 30 sampling population from each ward was selected randomly using simple random sampling techniques.

\subsection{Ethnobotanical Survey}

Before conducting the Ethnobotanical survey in both the village, we had a meeting with the leader of the village explaining our research objective. After getting verbal consent from the authority figure, the survey was conducted on the villages, and the respondents were categorized based on ethnic group. A total of 60 informants were interviewed and asked the $5 \mathrm{~W}+\mathrm{H}$ questions (viz. what, who, why, when, where, and how the respondents are utilizing the wild edible plants) to gain information on local name, usage, availability, species richness, threats, and opportunities of WEP. The informants freely stated their information and knowledge regarding the WEP available in the study area without being interfered.

\subsection{Research Instrument and design}

The pre-tested interview schedule was used to collect primary information. In addition, one focus group discussion and two key informant interviews were performed. Furthermore, secondary data were collected from various relevant journals, literature, and publications of different organizations. After data collection, it was thoroughly checked, coded, and entered for analysis. 


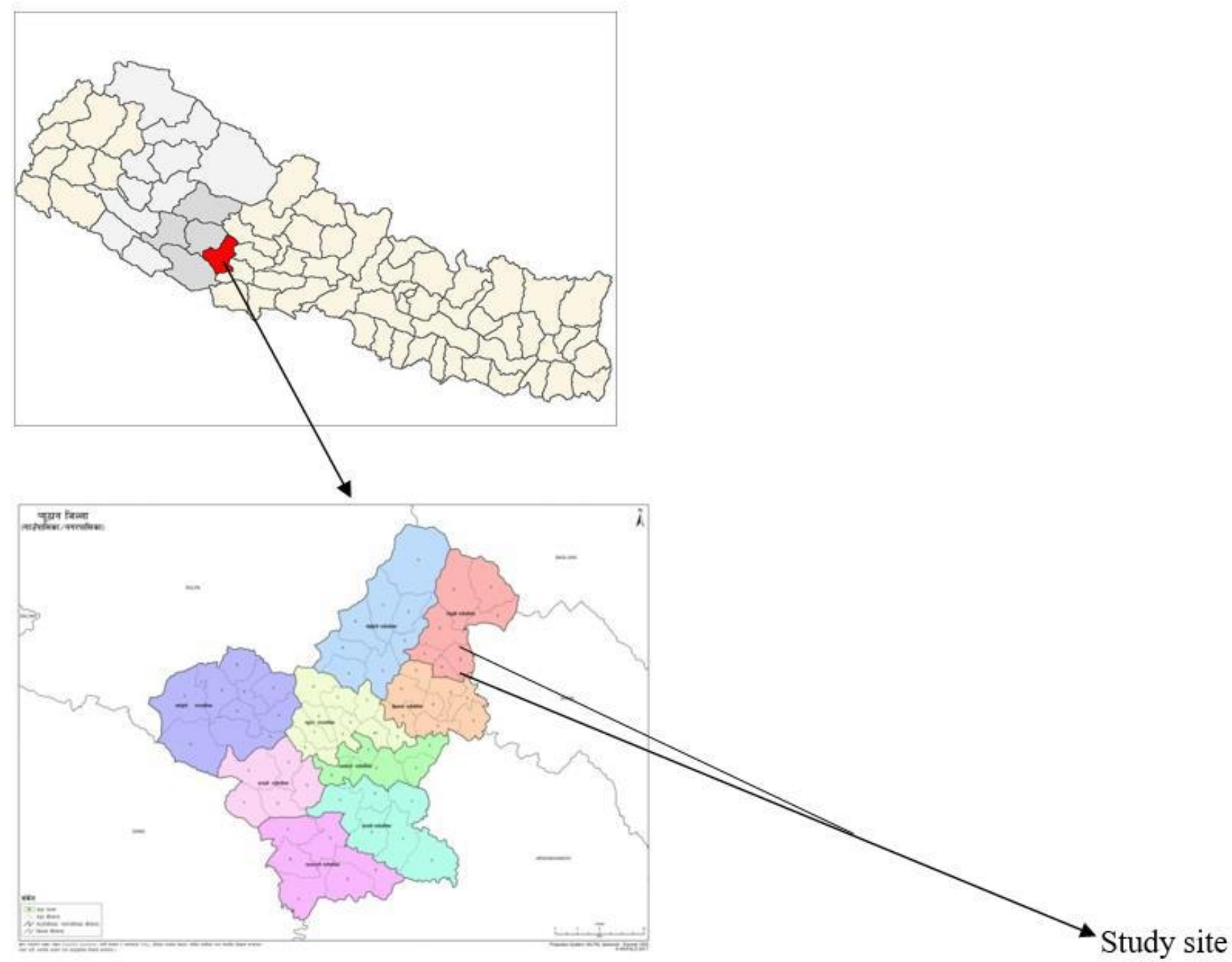

\subsection{Data Analysis}

After the data collection process, it was analyzed using both quantitative and qualitative analytical tools. Microsoft Excel sheet was used to organize the collected ethnobotanical data. The collected data was thoroughly checked, tabulated, and analyzed by SPSS software and RStudio.

Preference ranking was performed by Henry Garrett ranking method to analyze the most popular wild edible plants based on respondent's daily consumption. The percent position of each rank was obtained by the formula and then converted to the score from the table given by Henry Garrett.

Percentage position $=\frac{(\mathbf{1 0 0}(\boldsymbol{R} \boldsymbol{i} \boldsymbol{j}-\mathbf{0 . 5})}{\boldsymbol{N} \boldsymbol{j}}$ where,

$R_{i j}=$ Rank given for $i^{\text {th }}$ item $j^{\text {th }}$ individual

$\mathrm{N}_{\mathrm{j}}=$ Number of items ranked by $\mathrm{j}^{\text {th }}$ individual

\section{RESULTS AND DISCUSSIONS}

\subsection{List of WEP with its Local name, English name and Scientific name}

The local people of the study area mentioned about availability of various wild fruits, vegetables, and medicinal plants in the study area. Table 1 shows the list of local edible plants along with their English name and the scientific name which are majorly available and utilized by the respondents of the study area. 
Table 1: Name of Wild edible plants available in study area

\begin{tabular}{|c|c|c|c|}
\hline S.N & Local Name & English Name & Scientific Name \\
\hline 1 & Neuro & Fiddlehead fern & Diplaziumesculentum \\
\hline 2 & Tama & Tufted bamboo & Dendrocalamushamiltoni \\
\hline 3 & Sisnu & Stinging nettle & Nasturtium officinale \\
\hline 4 & Pudina & Mint & Mentha Spp. \\
\hline 5 & Silam & Perilla & Perillafrutescense \\
\hline 6 & Gurjo & Heart leaved moonseed & Tinosporacordifolia \\
\hline 7 & Ghodtapre & & Centellaasiatica \\
\hline 8 & Jaluka & Hitchhiker elephant ear & Remusatia vivipara \\
\hline 9 & Simesaag & Water cress & Nasturtium microphyllum \\
\hline 10 & Daude & Basket fern & Polystichumsquarrosum \\
\hline 11 & Khanayo & Drooping fig & Ficussemicordata \\
\hline 12 & Kabro & Java fig & Ficuslacor \\
\hline 13 & Koiralo & Mountain ebony & Bauhinia variegate \\
\hline 14 & Aiselu & Raspberry & Rubusellipticus \\
\hline 15 & Chutro & Rasanjan & Berberisaristata \\
\hline 16 & Teeju & Coromandel ebony & Diospyrosmelanoxylon \\
\hline 17 & Harro & Chebulicmyrobalan & Terminaliachebula \\
\hline 18 & Barro & Baheda & Terminaliabellerica \\
\hline 19 & Chiuri & Nepal butter tree & Diploknemabutyraceae \\
\hline 20 & Bidaulo & Cluster fig & Ficusracemosa \\
\hline 21 & Timilo & Common fig & Ficuscarica \\
\hline 22 & Bhakimlo & Macassar kernels & BruceajavanicaL.merr \\
\hline 23 & Ghanggaru & Nepalese firethorn & Pyracantharenulata \\
\hline 24 & Sil-timur & Mountain pepper & Litseacitrale \\
\hline 24 & Kaulo & Fragrant baytree & Perseaodoratissima \\
\hline 25 & Ban keraa & Wild banana & Musa balbisianacolla \\
\hline 26 & Ban tarul & Wild edible yam & Dioscoreabulbifera L. \\
\hline 27 & Mayal & Wild pear & Pyruspyraster \\
\hline 28 & Bhuikafal & False strawberry & Duehesneaindica \\
\hline 29 & Bhyakur & Deltoid kam & Dioscoranepalensis \\
\hline 30 & Amaro & Wild mango & Spondiaspinnata \\
\hline 31 & KadeDhania & Wild Coriander & Eryngiumfoetidium \\
\hline 32 & Paiyu & Wild cherry & Prunusnepalensis \\
\hline 33 & Salleuchyau & Wild Mushroom & Amanita chepangiana \\
\hline 34 & Bagalechyau & Wild Mushroom & Schizophyllum commune \\
\hline 35 & Phutuki & Wild Mushroom & Scleroderma texense \\
\hline
\end{tabular}




\begin{tabular}{|l|l|l|l|}
\hline 36 & Gobrechyau & Parasol mushroom & Macreolepiotaprocera \\
\hline 37 & Jharichyau & Deceiver mushroom & Laccarialaccata \\
\hline
\end{tabular}

\subsection{Taxonomical categories of WEP}

The figure 1 shows the categories of the wild edible plants that are available in the study site. According to the study, out of total wild plants mentioned by the 60 respondents, $27(45 \%)$ were trees followed by $16(26 \%)$ herbs, $13(22 \%)$ shrubs and $4(7 \%)$ climbers.

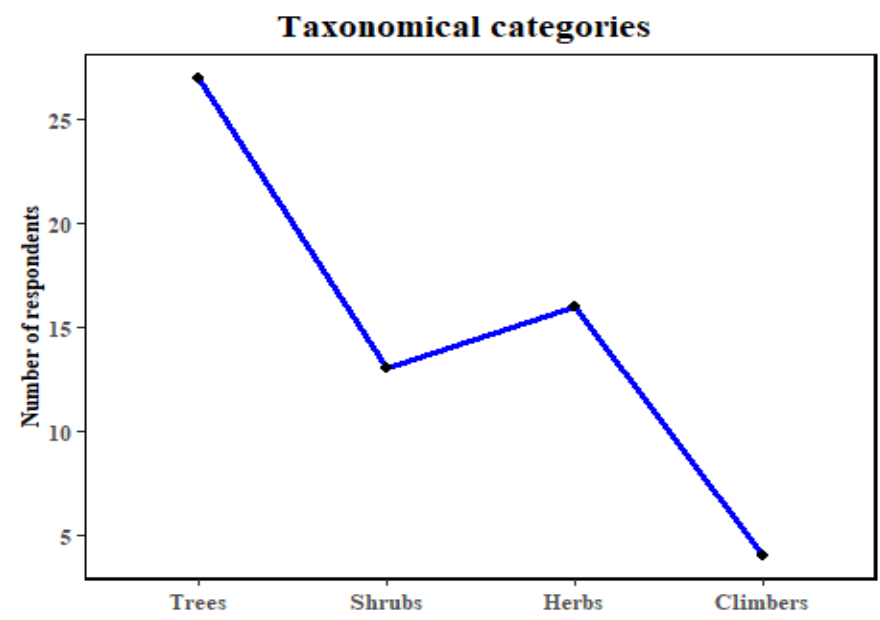

Fig 1: Taxonomical categories of WEPs

Source: Field survey

\subsection{Plant parts used as food}

Wild edible plants are used in various forms by the people in the study area. The figure 1 shows that majority of the wild edible plants (WEP) are used in the form of vegetables (54\%) followed by raw fruits (28\%) and pickle (12\%), oil (3\%) and spices $(3 \%)$.

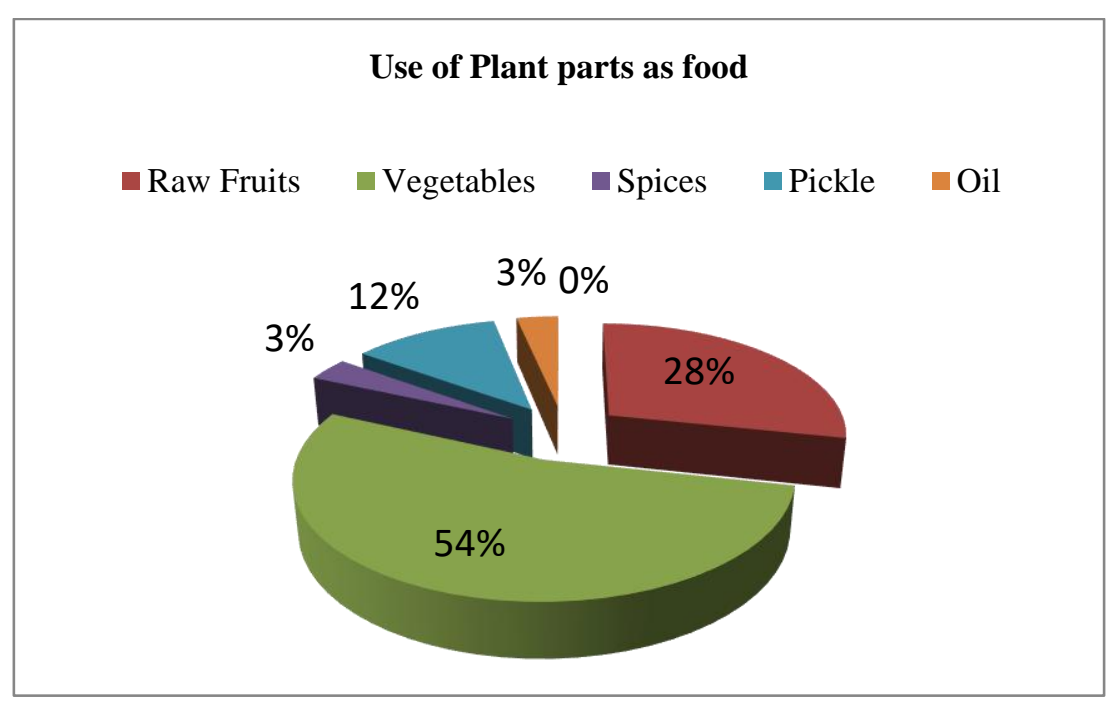

Fig 2: Parts of Plants used as food

Source: Field survey

\subsection{Distribution of WEP in different habitat}


Research shows that, mostly, the respondents collect wild edible plants from (60\%) forest area followed by (15\%) grazing land, (12\%) riverside, $(8 \%)$ roadside and (5\%) crop fields. (Fig 3)

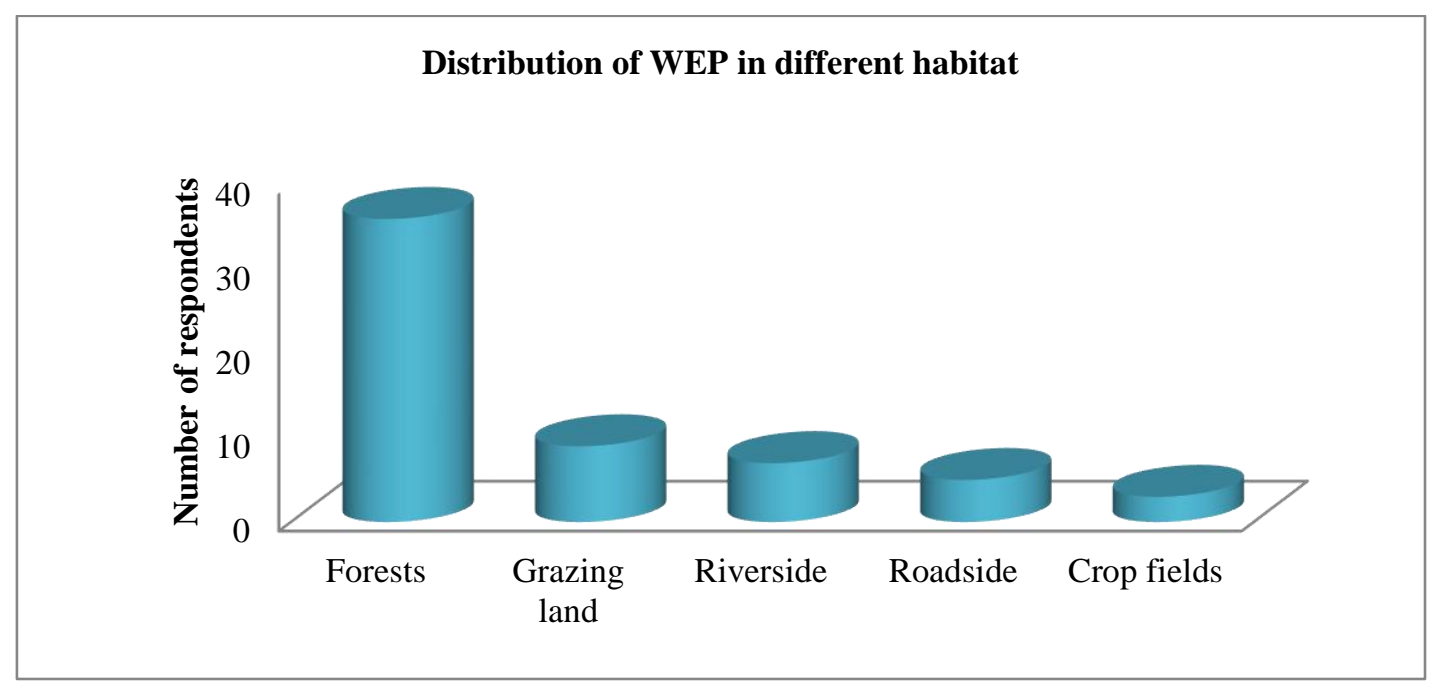

Fig 3: Distribution of Wild Edible Plants

Source: Field Survey

\subsection{Dependence on WEPs based on Ethnicity}

The respondents were categorized in four major ethnic groups; Brahmin, Chhetri, Dalits and Others. The others category in the study area includes Giri, Puri, etc.Fig 4 shows the findings of the study made to know and understand the dependence of respondents on wild edible plants on the basis of their ethnicity. The others category (39\%) was found to depend more on wild plants comparing to Dalits (36\%), Chhetri (15\%) and Brahmin $(10 \%)$.

\section{Dependence on WEPs}

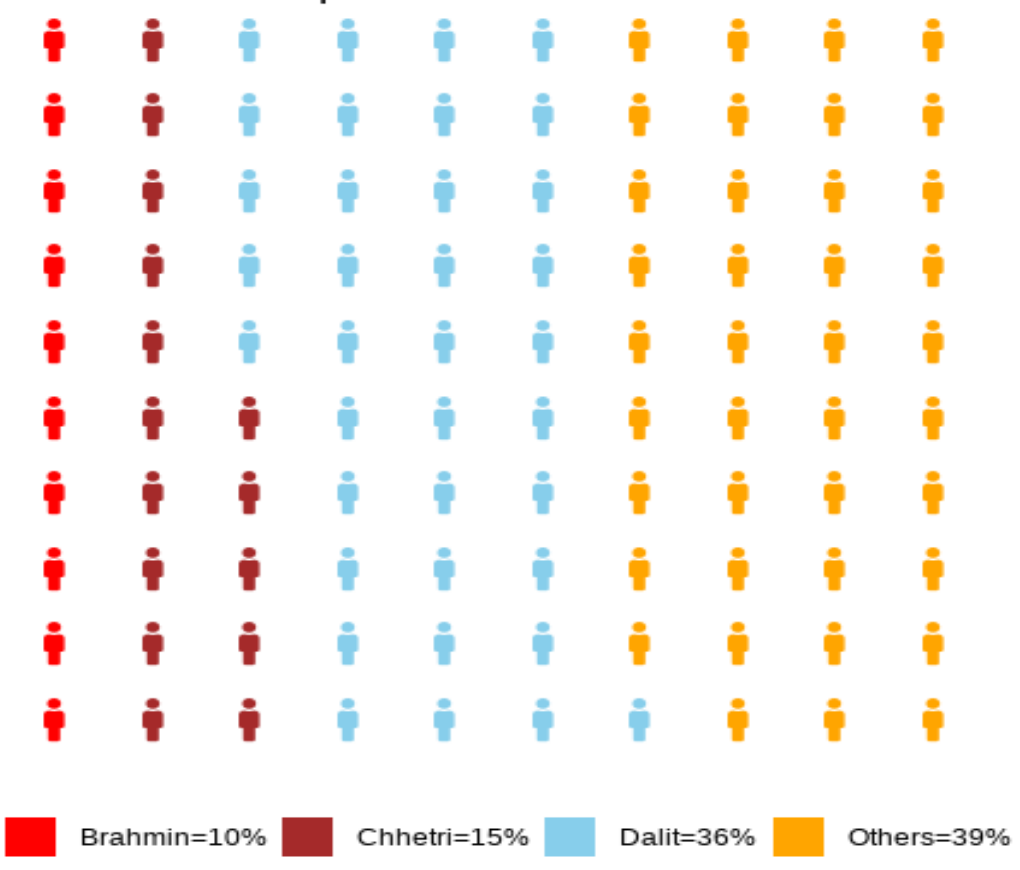

Fig 4: Dependence on WEPs based on ethnicity

Source: Field survey 


\subsection{Species richness of WEP along the elevation gradient}

On studying the species richness of WEP's in the Gaumukhi area, the highest diversity of the plants were found in the altitude range of (1300-1500)masl and the lowest diversity of the plants was found at the altitude of 2250 masl. The fig 5 shows the result of this study species richness of wild plants along with its elevation gradient. It is in line with the research paper(Babu Ram Nepali, 2020) conducted in Arghakhachi district of Nepal.

Species Richness of WEPs of Gaumukhi Rural

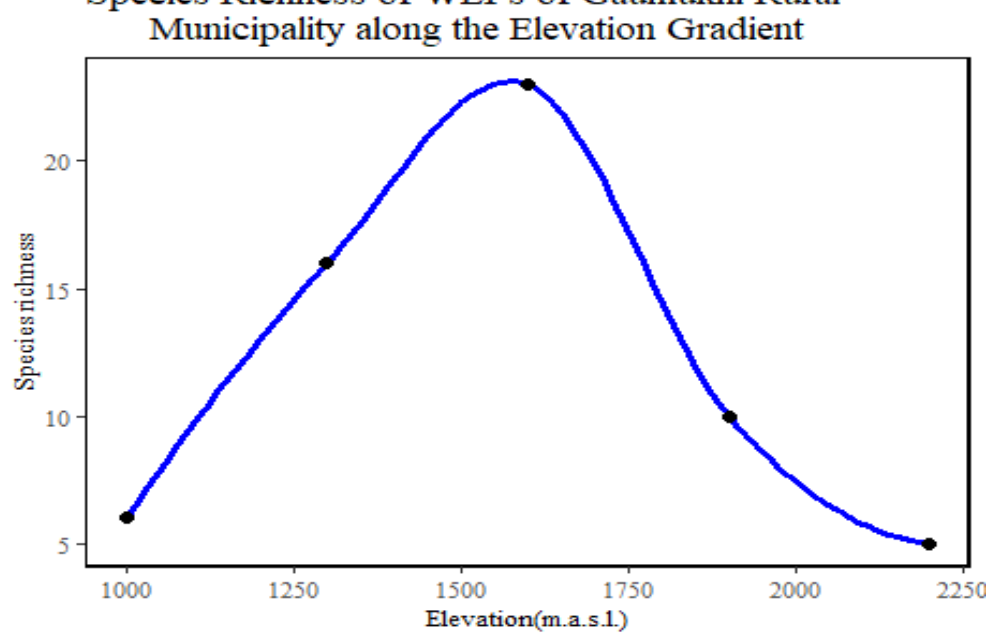

Fig 5: Species richness along the elevation gradient

Source: Field survey

\subsection{Threat to wild edible plants}

On studying the several threats to wild edible plants available in study area, research shows that fuel wood collection was found to be the major problem to conserve the wild plants followed by uncontrolled fire and problem of over grazing (Fig 6).

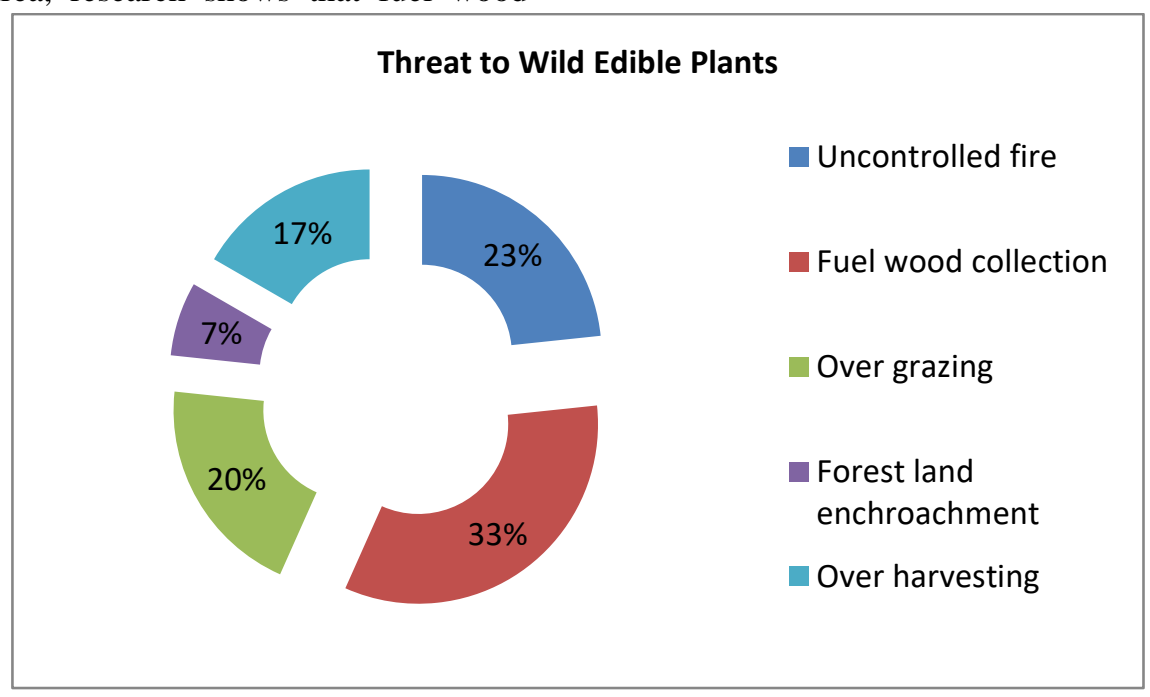

Fig 6: Threats to Wild Edible Plants

Source: Field survey

\subsection{Preference of WEP in study area}

Based on daily consumption by the respondents of study area, the preference of WEP is ranked by Henry Garrett ranking method. Among the different crops listed by respondents, Dauderanked first followed by Neuro, Tama, Sisnu and Simesaag.

Table 2: Preference of wild edible plants

\begin{tabular}{|l|l|l|}
\hline Wild Edible Plant Species & Average Score & Ranking \\
\hline
\end{tabular}




\begin{tabular}{|l|l|l|}
\hline Polystichumsquarrosum(Daude) & 64.5 & I \\
\hline Diplaziumesculentum (Neuro) & 60 & II \\
\hline Dendrocalamushamiltoni(Tama) & 46.4 & III \\
\hline Nasturtium officinale(Sisnu) & 37.6 & IV \\
\hline Nasturtium microphyllum(Simesaag) & 35.6 & V \\
\hline
\end{tabular}

\section{CONCLUSION}

Most of the wild plants available in the study area were found to be edible. The objective of our study was to understand and record the local knowledge on indigenous plants which are available in the Gaumukhi area of the Pyuthan district. The study was focused to promote the neglected plants which have high value in terms of nutrients and medicine. The result of our research survey shows that the WEP are not only a good source of nutrients and food to local communities but also, can be used as means of income generation by the local population. The study highlights the ethnicity of the people in the study area and their dependence on wild plants. The study revealed information about edibility, natural habitat, and plant parts used as food. These multi-valued plants are in threat by causes such as fuelwood collection, uncontrolled fire, overgrazing, forest land encroachment, and over-harvesting. Conservation and sustainable management of these resources could be a great contribution to local communities as well as biodiversity. Encouraging the youth of communities rather than consulting elders for the information and knowledge on wild plants could be helpful to conserve these valuable resources. The study we made on ethnobotanical research on wild plants from different ethnic groups located in the study area could be the key data to promote the importance of wild edible plants and conservation of cultural traditional value among the youngsters. The wild plants, if conserved, could turn into a profitable crop and also contribute to the sustainable use of natural resources by safeguarding the endangered species.
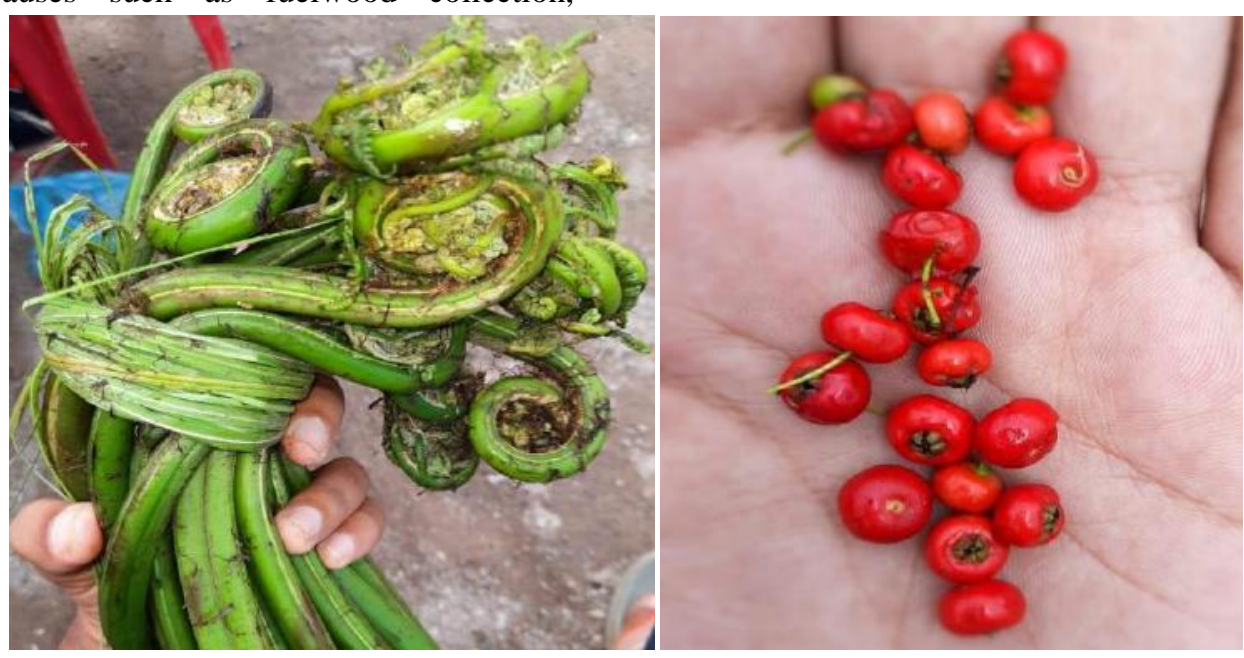

Fig.7: DaudeFig: Ghanggaru

(Polystichumsquarrosum)(Pyracantharenulata) 

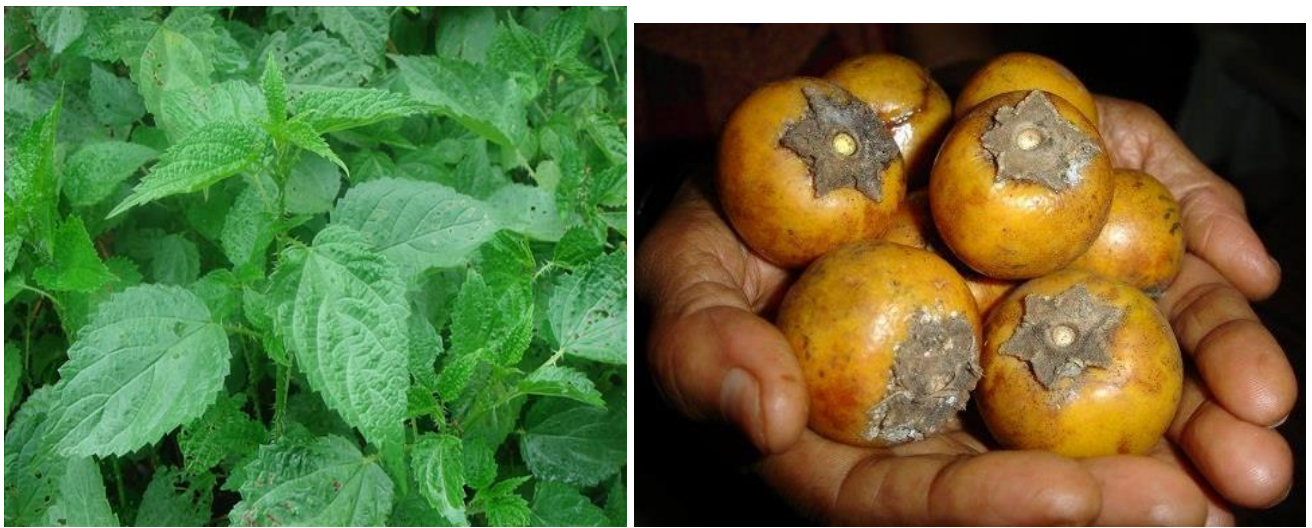

Fig.8: SisnuFig: Teeju

(Nasturtium officinale) (Diospyrosmelanoxylon)

\section{REFERENCES}

[1] Nepali B.R, Skartveit J, Baniya C.B (2020). Interpolated Altitudinal Species Richness in Arghakhachi district of Nepalhttps://www.nepjol.info/index.php/JIST/article/view/ 29447

[2] Dangol D.R, Maharjan K.L, Maharjan S.K, Acharya A.K (2017). Wild Edible Plants of Nepal; Conservation and Utilization of Agricultural Plant Genetic Resources in Nepal

[3] Gautam R.S, Shrestha S.J, Shrestha I (2020). Wild Edible fruits of Nepal

[4] Bhatia H, Sharma Y.P, Manhas R.K, Kumar K (2018). Traditionally used wild edible plants of district Udhampur, $\mathrm{J} \& \mathrm{~K}$, India;Journal of Ethnobiology and Ethnomedicine .https://ethnobiomed.biomedcentral.com/articles/10.1186/s 13002-018-0272-1

[5] Balemie K,Kebebew F (2006). Ethnobotanical study of wild edible plants in Derashe and Kucha Districts, South Ethiopiahttps://ethnobiomed.biomedcentral.com/articles/10 .1186/1746-4269-2-53\#Abs1

[6] Acharya K.P,Acharya R (2010). Eating From the Wild: Indigenous Knowledge on Wild Edible Plants in Parroha VDC of Rupandehi District, Central Nepal; International Journal of Social Forestry

[7] Lockett C, Calvert C, Grivetti L.E (2000). Energy and micronutrient composition of dietary and medicinal wild plants consumed during drought, study of rural Fulani, northeastern Nigeria. International Journal of Food Sciences and Nutrition .

[8] Ashagre M, Asfaw Z, Kelbessa E (2016). Ethnobotanical study of wild edible plants in Burji district, Segan area zone of Southern Nations, Nationalities and Peoples Region(SNNPR), EThiopia. Journal of Ethnobiology and Ethnomedicine .

[9] Mahato, R.B (2014). WILD EDIBLE FRUITS OF PALPA DISTRICT, WEST NEPAL.

[10] Manandhar, N.P (2002). Plants and People of Nepal. Timber Press Portland Oregon,USA .

[11] Manandhar, N.P (1982). Wild edible plants of Nepal. Thapathali,Kathmandu: Bull. Dept. Med. Pl.,No.11.
[12] MoFSC. (2014). National biodiversity stratgey and action plan 2014-2020, Ministry of Forests and Soil Conservation. Singhadurbar,Kathmandu,Nepal: Government of Nepal.

[13] Uprety Y, Poudel R.C, Shrestha K.K, Rajbhandary S, Tiwari N.N, Shrestha U.B, Asselin H (2012). Diversity of use and local knowledge of wild edible plant resources in Nepal; Journal of Ethnobiology and Ethnomedicine

[14] Cao Y, Li R, Zhou S, Song L, Quan R, Hu H (2020). Ethnobotanical study on wild edible plants used by three trans-boundary ethnic groups in Jiangcheng County, Pu'er, Southwest China; Journal of Ethnobiology and Ethnomedicine 